\title{
Electricity decarbonisation pathways for 2050 in Portugal: A TIMES (The Integrated MARKAL-EFOM System) based approach in closed versus open systems modelling
}

\author{
Filipa Amorim ${ }^{\mathrm{a}, *}$, André Pina ${ }^{\mathrm{a}}$, Hana Gerbelováa ${ }^{\mathrm{a}}$, Patrícia Pereira da Silva ${ }^{\mathrm{b}, \mathrm{c}}$, \\ Jorge Vasconcelos ${ }^{\mathrm{a}}$, Victor Martins ${ }^{\mathrm{d}}$ \\ ${ }^{a}$ MIT Portugal Program - Sustainable Energy Systems, IN+, IST, Universidade de Lisboa, Av. Professor Aníbal Cavaco Silva, 2744-016 Porto Salvo, Portugal \\ ${ }^{\mathrm{b}}$ MIT Portugal Program - Sustainable Energy Systems, FEUC, Universidade de Coimbra, Av. Dias da Silva, 165, 3004-512 Coimbra, Portugal \\ ${ }^{\mathrm{C}}$ INESCC, Rua Antero de Quental, 199, 3000-033 Coimbra, Portugal \\ ${ }^{\mathrm{d}}$ MIT Portugal Program - Sustainable Energy Systems, ISEG, Universidade Técnica de Lisboa, Rua Miguel Lupi, 20, 1200-725 Lisboa, Portugal
}

\section{A R T I C L E I N F O}

\section{Article history:}

Received 2 August 2013

Received in revised form

10 January 2014

Accepted 15 January 2014

Available online 11 February 2014

\section{Keywords:}

Iberian electricity market (MIBEL)

The integrated MARKAL-EFOM system

(TIMES)

Roadmap 2050

Renewable electricity

Hourly dynamics

\begin{abstract}
A B S T R A C T
The goal of this research is to analyse the cost-effective opportunities in continental Portugal to achieve full decarbonisation of the electricity generation sector by 2050. Since interconnection with neighbouring Spain may be one of the key drivers to achieve a cost-effective low carbon pathway, combined with new generating technologies, we evaluate its importance by modelling the Portuguese system either as an isolated or as part of an integrated Iberian system.

To design the low carbon roadmap for 2050 in Portugal, TIMES - The Integrated MARKAL-EFOM (MARKet ALlocation-Energy Flow Optimisation Model) System was used. It is an optimization partial equilibrium bottom-up model generator that finds the minimal cost solution for an energy system over a certain time period. Our approach accounts for the short term dynamics of supply and demand to enable a better match and optimize resources complementarities.

The results show that modelling Portugal as an isolated system can lead to underinvestment and underuse of the country's endowment of renewable energy sources in the longer term, which reduces the efficiency of investment. The modelling of Portugal as an interconnected energy system can therefore have a significant impact on the design of a sustainable electricity system and lead to improved investment efficiency with lower costs risk.
\end{abstract}

(c) 2014 Elsevier Ltd. All rights reserved.

\section{Introduction}

The transition to a post carbon society is in place in Europe and in the world [1-3]. The implications of the European decarbonisation strategy have been analysed in several studies which indicate the need to fully decarbonise the EU electricity system(s) by 2050 [4-8]. This sector has been the most advanced in integrating increasing amounts of RES (renewable energy sources) once it represents the largest source of $\mathrm{CO}_{2}$ emissions and is by far the sector with highest potential, owing to the large number of low emission generation technologies available. Moreover, the electricity sector can contribute to reduce emissions in other energy intensive sectors through their electrification.

\footnotetext{
* Corresponding author. Tel.: +351917443151.

E-mail addresses: filipa.amorim@ist.utl.pt, amorim.filipa@gmail.com (F. Amorim).
}

The massive integration of unevenly distributed and variable RE (renewable electricity) expected for the decades to come, along with the need to cope with increasing flexible resources such as distributed generation, demand-side participation (e.g. higherperformance building and demand response), novel storage technologies (e.g. electric vehicles and thermal storage) or more integrated transnational networks bring to the forefront of policy concerns new unintended challenges that must be carefully addressed in a long-term framework [9-11]. To date, the current regulations in place do neither incentivize an active variable RE or demand side participation in the market(s) nor an active role in balancing and reserves management. Also more innovation and intelligence is needed in the networks both at transmission and distribution level, in particular, through information and communication technologies [12]. Additionally, barriers to cross-border trade need to be removed because they offer prospects of additional flexibility and efficiency gains $[13,14]$. 
Mostly due to the diversity and increasing amounts of available RE generation technologies, the liberalization trend of electricity markets and the increasing decentralization of energy production units, long term energy systems planning models need to be more realistic and complex than ever before. Expanding computational possibilities have been enabling responses to the various challenges. In the last few decades a large number of energy tools have appeared with a wide variety of possible applications. Van Beeck (1999) [[15], page17] presents nine dimensions to classify energy models, which are not mutually exclusive, and can help in the search of the best suit of existing tools to a specific research end. Several authors have classified energy system models using these dimensions [16-19]. Bhattacharyya et al. (2010) [17] review different types of models with the objective of assessing their suitability for African developing countries, also treated in Refs. [20-22]. In Ref. [18] a detailed comparison of 37 energy tools used for analysing the integration of renewable energy in various energy systems is carried and accompanied of a short model description. In Ref. [19] 90 energy system tools are compared to support the conclusion that the most commonly used modelling methodologies are not prepared to perform long-term analysis of energy systems, these lack the required temporal resolution to represent supply and demand dynamics and, consequently, have a limited ability to capture the impact of energy efficiency measures and of the increased use of renewable energies.

The meso-scale gap has been identified by several authors [2329] who have brought closer long and short term approaches using different strategies. The authors in Ref. [26] developed the LIMES (Long-term Investment Model for the Electricity Sector), while the authors in Ref. [27] opted for an extension of the TIMES (The Integrated MARKAL-EFOM (MARKet ALlocation-Energy Flow Optimisation Model) System) model for the optimization of investment in electricity generation considering high temporal resolution of supply and demand. In Ref. [28] the authors also used the TIMES model but combined it with the short-term model for the optimization of the operation of the system EnergyPLAN; in Ref. [29] the authors again used the TIMES model but linked it to a power systems model software, PLEXOS. Hybrid frameworks, combining more than one model, tend to be more complex and consuming in terms of computational resources.

Modelling developments in energy systems analysis have been obtained using either theoretical models [25] or applications to single region systems $[24,26,28,30]$. Therefore, they are unsuitable to analyse how systems integration issues affect long term investment decisions. To the authors knowledge, only the authors in Ref. [31] have presented a model for multi scale systems analysis, despite EU and MENA (Middle East and North Africa) regions are treated as aggregated regions and the diversity within each is not taken into account. Also, the model has a temporal resolution of $6 \mathrm{~h}$ and does not capture dynamics at smaller time scales.

Foley et al. (2010) [32] provide an overview of electricity systems modelling techniques, in particular, with key responses to recent design changes and describe seven of the most used electricity system models worldwide. Interesting conclusions are drawn concerning the selection of a model to analyse long-term planning of electricity systems [32] namely that technical, socio-economic and environmental factors are not properly considered in most electricity systems models, which must be a consequence of most of the models being developed for their customers, who seek short to medium term profits. Also that electricity systems models do not represent renewable energy sources realistically, particularly in their stochastic nature of variable intermittency and that most models assume perfect competition market conditions. Finally, the authors argue that long term generation expansion planning does not appear as a priority. Most common applications to system expansion planning use
20-30 years horizon at maximum as in the application of the model EMCAS (Electricity Market Complex Adaptative System) to the Iberian case [33] or in the model WASP (Wien automatic system planning) to the case of Oman [34].

Based on the number of users, on the fit of the model to analyse long term energy systems planning with focus in the electricity sector at national or multi-national levels and on their suitability to address some details on temporal resolution of supply and demand of energy as required to develop the analysis of the decarbonisation pathways to 2050 in Portugal in closed versus open system modelling as performed herein, a short description of the most suited energy system models follows.

The Wien Automatic System Planning (WASP) is a generation and operation expansion planning model for the electricity system developed by the IAEA (International Atomic Energy Agency) currently in it's fourth edition which initiated in 1992. WASP-IV is designed to find the economically optimal expansion policy for an electric utility system within user specified constraints. It utilises probabilistic estimation of system production costs, unserved energy costs and reliability. The linear programming technique is used for determining optimal dispatched policy satisfying exogenous constraints on environmental emissions, fuel availability and electricity generation by some plants, while the dynamic programming method is used for optimising the costs of alternative system expansion policies [35]. The maximum allowed number of years under study is 30 and of the periods per year is 12 [[35], page11]. Therefore, despite some temporal resolution it is not a model particularly suited to represent renewable sources intermitency in the 2050 planning horizon. Some applications with this tool can be read in Refs. [34,36,37].

The MARKet ALlocation (MARKAL) model is a widely applied bottom-up and dynamic linear programming model developed by the ETSAP (Energy Technology Systems Analysis Programme) of the IEA (International Energy Agency). MARKAL is a generic model tailored by the input data to represent the evolution over a period of usually 40-50 years of a specific energy system at national, regional, state, province or community level. This system can be an integrated energy system or a single electricity system. It is used with time-periods that are usually of 5 or 10 years long, but also allows some resolution as it recognizes three seasons (Winter, Summer and Intermediate) and two diurnal divisions (Day and Night). The basic components in a MARKAL model are specific types of energy or emission control technology. A menu of both existing and future technologies is input to the model as is the projections of energy service demands and projected resource costs. Both the supply and demand sides are integrated, so that one side responds automatically to changes in the other. The model selects that combination of technologies that minimizes total energy system cost. The Integrated MARKAL-EFOM system (TIMES) is an evolved version of MARKAL and of the Energy Flow Optimisation Model (EFOM) with new functions and flexibilities, also developed within the ETSAP. The main advantage that TIMES has regarding its predecessors is its flexibility once it is possible to sub-divide the year in several time periods with different user defined lengths. Also it is possible to have different levels of disaggregation for different sectors and the option of making investment in blocks. Given that the model uses an optimization algorithm and has a very large technology and commodities base, special attention must be given to the number of time periods because these have a large impact on the computational complexity of the model.

\section{Scope and structure of the article}

This paper presents a modelling exercise to optimize the investment in new electricity generation capacity in the long-term 


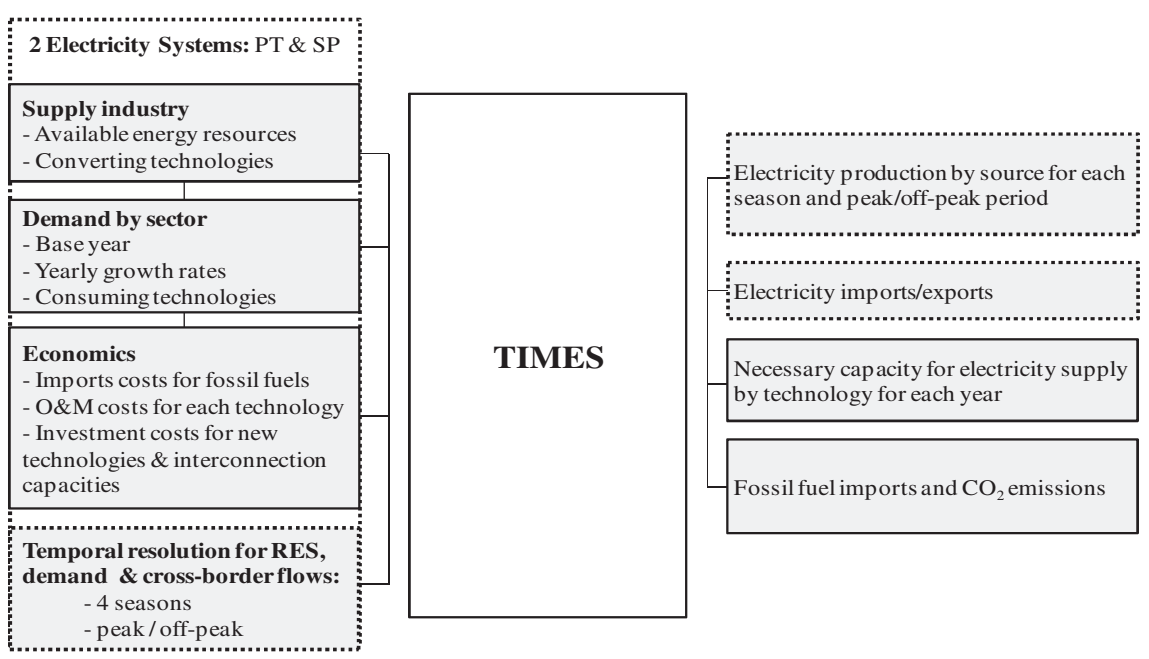

Fig. 1. Main inputs and outputs of a typical TIMES model for electricity systems.

with the goal of achieving significant $\mathrm{CO}_{2}$ emissions reductions, taking into account not only hourly dynamics of supply and demand, but also another important model development, the interplay between adjacent systems. The main objective of the paper is, therefore, to highlight the significance of considering open systems in energy system modelling analysis and understand how systems integration affect long-term investment decisions. To that end, the modelling implementation was conducted to mainland Portugal for the time period of 2005-2050, under the constraint of full $\mathrm{CO}_{2}$ emissions reduction by 2050, and two scenarios - one in which Portugal is seen as an isolated system and another in which exchanges with neighbouring Spain are considered.

To design the low carbon technological roadmap for 2050 in Portugal, the TIMES model was used. TIMES is an optimization partial equilibrium bottom-up model generator that minimizes the total cost of an energy system over a certain time period. The model is based on detailed and explicit information about available energy technologies (e.g. production capacity, efficiency and all sorts of costs, namely, investment, fixed and variable concerning operation and maintenance and fuel) and the description of end-use consumption of different sectors and types of energy. It is usually applied to the analysis of the entire energy sector, but may also be applied to study in detail single sectors (e.g. the electricity and district heat sector) [38].

Analyses looking into the planning of Portuguese low carbon energy systems future have been developed, either concerning the whole energy sector [39-41] or the electricity sector alone $[28,30,42]$. None of these, however, include the increasingly relevant interactions with the Spanish electricity system [43], ignoring the deepening integration under the MIBEL (Iberian Electricity Market), which our approach considers.

The remaining of this paper is structured as follows. Section 3 describes in more detail the framework of the developed PT/SP (Portugal/Spain) TIMES model. Sections 4 and 5 characterize the analysed adjacent electricity systems, Portugal and Spain, respectively. Section 6 reviews the modelling scenarios and assumptions used in the analysis. Section 7 presents the results and, finally, Section 8 concludes.

\section{The PT/SP TIMES model}

TIMES was introduced in 1999 as the latest development of the MARKAL framework maintained by the IEA's ETSAP $[44,45]$. It is being developed by several researchers related to ETSAP such as Gary Goldstein, Amit Kanudia, Richard Loulou, Uwe Remme and Giancarlo Tosato. The model is built through a detailed description of technologies and commodities that characterize the energy system and selects the combination of technologies that minimize total energy system costs, including investment, operation and maintenance, activity and fuel costs.

The main advantage of TIMES is its flexibility, which allows integrating more than one interacting regions and to sub-divide the year in several time periods with different lengths defined by the user. A typical TIMES model for the evolution of an electricity system can be represented as shown in Fig. 1. Additional inputs and outputs are represented in the dashed lines to account for exchanges between two adjacent systems and to increase time resolution (adapted from Ref. [27]).

The PT/SP TIMES model considers the interconnection between two adjacent systems. The direction, intensity and time-dynamics of the interconnection's use varies along with time (year/season/ hours) as it may be expected due to, for instance, time-zone differences and each region typical consumption profiles or the relative competitive advantage of electricity at certain time-periods in result of the different availability of resources in each system. The model considers 288 time periods each year: 4 Seasons, 3 typical days per Season and $24 \mathrm{~h}$ per day are considered. The typical days considered in the model are 1 Weekday, 1 Saturday and 1 Sunday. This division of the year enables the modelling of several different supply and demand dynamics. The data required to allow for this higher resolution was based on information made available by the Portuguese and the Spanish Independent Transmission System Operators [46-48]. In the case of a system with high penetration from renewable energies, this fine time resolution enables the analysis of possible advantages of using/building interconnections to import from or to export to the neighbouring country. Historically, interconnection capacity was built based in principles of energy security; more recently, these worries have been overlaid by cost-competitiveness principles.

\section{The Portuguese electricity system}

\subsection{General}

Last decades transformations in the Portuguese electricity system highlight the efforts to cope with the goals of European 
Climate/Energy Policy in parallel to the construction of a single European energy market [49]. To this end, we have assisted to the substitution of more polluting fossil fuelled generation by less polluting and diversified sources of fuel, such as endogenous renewable energy sources and natural gas, along with investments in new and upgraded grids, both for internal use and for exchanges with the neighbouring system. This has contributed to the reduction of the external fuel dependence and import costs.

Tables 1 and 2 express the evolution of the Portuguese electricity from 2005 to 2010 . Table 1 shows total installed capacity [50] while Table 2 shows the interconnection available [51].

\subsection{Expected evolution}

Following the European Directive 2009/28/EC [52], Portugal designed in 2010 a National Action Plan for Renewable Energies which defines the objectives relative to the quotas of RES in the Electricity, Transportation and Cool and Heating sectors up to 2020 [53]. This Plan is subject to bi-annual updates, the latest of which has been recently performed in 2012, in light of the changes in the macroeconomic scenarios analysed, the policy setting and the realized investments in the energy sectors. In what concerns the electricity sector, the expected installed capacity additions and retirements in the Portuguese electricity system up to 2020, based in the expectations built as of 2011, have been comprehensively described in Refs. [49,54]. Some of these investments are still currently being re-scheduled, others re-defined, while considerable uncertainty still persists within the possible evolutions of the sector. Table 3 below shows the revised RES installed capacity objectives by the Portuguese Government and compares them with the initial plan. These mean that, until 2020, no other RES investments are expected besides those that are currently under construction or licensed. A disincentive is therefore noticed in less mature technologies such as waves, solar, or offshore wind. Overall, the revised Plan foresees a reduction of $19 \%$ in total RES installed capacity by 2020 , despite the relative quota of RES in electricity is estimated to be higher than previously set (58\% versus 55\%) [55].

\section{The Spanish system}

The Spanish system has experienced similar transformations to those in Portugal towards decarbonisation and integration of its electricity system. Spain is presently among the top 10 countries in the world with non-hydro renewable (wind and solar) installed capacity [56]. Table 4 shows the evolution of the Spanish electricity system in what concerns the installed capacity from 2005 to 2010 [57].

While the interconnection between Portugal and Spain has been expanding and is expected to increase by $1.200 \mathrm{MW}$ in 2014/
Table 2

Average of hourly commercial available interconnection capacity.

\begin{tabular}{lllllll}
\hline MW & 2005 & 2006 & 2007 & $2008^{\text {a }}$ & 2009 & 2010 \\
\hline Spain to Portugal & dna & dna & dna & 1216 & 1204 & 1112 \\
Portugal to Spain & dna & dna & dna & 1049 & 1192 & 1183 \\
\hline
\end{tabular}

a Second semester; dna: data not available.

Table 3

Total installed capacity of renewable energy sources updated.

\begin{tabular}{llc}
\hline MW & 2020 & Var. face to NREAP* 2010 \\
\hline Large and small hydro & 8932 & $-6 \%$ \\
Thermal RES & 747 & $-22 \%$ \\
Wind & 5300 & $-23 \%$ \\
Solar & 550 & $-63 \%$ \\
Waves & 6 & $-98 \%$ \\
Total & 15535 & $-19 \%$ \\
\hline
\end{tabular}

NREAP - National Renewable Energy Action Plan.

2015, to $3.000 \mathrm{MW}$ of commercially available capacity, the interconnection between Spain and France (therefore Iberian and Central European systems) and between Spain and Morocco (Iberian/ EU and North African systems) is still relatively limited. The Iberian interconnection will represent about $25 \%$ of Portuguese peak demand, which is more than the minimum amount agreed at the European Council of March 2002. The EU recommends that interconnection capacity should represent at least $10 \%$ of peak demand of the smaller interconnected system. In the period 2005-2010, only in the French borders Spain has been a net importer, while with Portugal, Morocco and Andorra it has been a net exporter [57].

\section{Modelling scenarios and assumptions}

\subsection{General}

Given the difficult economic context in Europe and the uncertainty of future investments in new generating capacity both in the Portuguese and Spanish electricity systems, the approach used in this work has been to leave the model free to decide on the most cost-efficient investments up to 2050 under the condition of $60 \%$ decarbonisation of the electricity sectors by 2030 and $95 \%$ reduction in 2050 (relative to 1990 emissions). The model calibration has been done for the period 2005-2010. One scenario assumes Portugal as an isolated system, while the other scenario considers the export/ import balances of electricity in the Iberian electricity systems. In the first scenario a detailed characterisation of the Portuguese system was required, while the second also includes a thorough characterisation of the Spanish generation system, put under similar environmental constraints of decarbonisation by 2050 as the

Table 1

Generation capacity in Portuguese electricity system.

\begin{tabular}{|c|c|c|c|c|c|c|c|c|c|c|c|c|}
\hline \multirow{2}{*}{$\frac{\text { MW }}{\text { Total }}$} & \multicolumn{2}{|l|}{2005} & \multicolumn{2}{|l|}{2006} & \multicolumn{2}{|l|}{2007} & \multicolumn{2}{|l|}{2008} & \multicolumn{2}{|l|}{2009} & \multicolumn{2}{|l|}{2010} \\
\hline & 12,819 & $\%$ & 13,616 & $\%$ & 14,197 & $\%$ & 14,924 & $\%$ & 16,661 & $\%$ & 17,915 & $\%$ \\
\hline Large hydro & 4578 & 36 & 4578 & 34 & 4578 & 32 & 4578 & 31 & 4578 & 27 & 4578 & 26 \\
\hline Coal & 1776 & 14 & 1776 & 13 & 1776 & 13 & 1776 & 12 & 1756 & 11 & 1756 & 10 \\
\hline Fuel \& oils & 1909 & 15 & 1909 & 14 & 1877 & 13 & 1877 & 13 & 1878 & 11 & 1822 & 10 \\
\hline Natural gas & 2166 & 17 & 2166 & 16 & 2166 & 15 & 2166 & 15 & 2992 & 18 & 3829 & 21 \\
\hline Other thermal $^{\mathrm{a}}$ & 1166 & 9 & 1295 & 10 & 1365 & 10 & 1463 & 10 & 1610 & 10 & 1696 & 9 \\
\hline Small hydro & 333 & 3 & 365 & 3 & 374 & 3 & 379 & 3 & 395 & 2 & 410 & 2 \\
\hline Wind & 891 & 7 & 1515 & 11 & 2048 & 14 & 2624 & 18 & 3357 & 20 & 3702 & 21 \\
\hline Solar & 0 & 0 & 0 & 0 & 13 & 0 & 50 & 0 & 95 & 1 & 122 & 1 \\
\hline Waves & 0 & 0 & 0 & 0 & 0 & 0 & 2 & 0 & 0 & 0 & 0 & 0 \\
\hline
\end{tabular}

a Thermal under special regime includes biomass, biogas, co-generation, municipal waste sewage. 
Table 4

Generation capacity in the Spanish electricity system.

\begin{tabular}{|c|c|c|c|c|c|c|c|c|c|c|c|c|}
\hline \multirow{2}{*}{$\frac{\text { MW }}{\text { Total }}$} & \multicolumn{2}{|l|}{2005} & \multicolumn{2}{|l|}{2006} & \multicolumn{2}{|l|}{2007} & \multicolumn{2}{|l|}{2008} & \multicolumn{2}{|l|}{2009} & \multicolumn{2}{|l|}{2010} \\
\hline & 73,970 & $\%$ & 78,753 & $\%$ & 85,698 & $\%$ & 90,879 & $\%$ & 93,729 & $\%$ & 99,043 & $\%$ \\
\hline Large hydro & 16,657 & 23 & 16,657 & 21 & 16,657 & 19 & 16,657 & 18 & 16,657 & 18 & 17,561 & 18 \\
\hline Nuclear & 7876 & 11 & 7716 & 10 & 7716 & 8 & 7716 & 8 & 7716 & 8 & 7777 & 8 \\
\hline Coal & 11,424 & 15 & 11,424 & 15 & 11,357 & 12 & 11,359 & 12 & 11,359 & 12 & 11,380 & 11 \\
\hline Fuel \& oils & 6647 & 9 & 6647 & 8 & 4810 & 5 & 4418 & 5 & 3008 & 3 & 2860 & 3 \\
\hline Natural gas & 12,224 & 17 & 15,500 & 20 & 20,958 & 24 & 21,675 & 24 & 23,066 & 25 & 25,235 & 25 \\
\hline Small hydro & 1758 & 2 & 1809 & 2 & 1913 & 2 & 1979 & 2 & 1974 & 2 & 1991 & 2 \\
\hline Wind & 9800 & 13 & 11,140 & 14 & 13,909 & 17 & 15,874 & 17 & 18,719 & 20 & 20,057 & 20 \\
\hline Solar PV & - & & - & & - & & - & & - & & 3458 & 3 \\
\hline Solar thermal & - & & - & & - & & - & & - & & 682 & 1 \\
\hline Thermal RES & 939 & 1 & 1091 & 1 & 1507 & 4 & 4069 & 4 & 4480 & 5 & 1050 & 1 \\
\hline Thermal non RES & 6645 & 9 & 6769 & 9 & 6871 & 8 & 7132 & 8 & 6750 & 7 & 6992 & 7 \\
\hline
\end{tabular}

Portuguese, including their interconnections. For both scenarios, the evolution through time of electricity demand, fuel prices, cost of technologies and demand and resource dynamics were the same.

\subsection{Assumptions}

For the evolution of electricity demand in Portugal, we considered the joint evolution of gross domestic product and power intensity [4] under the projections of the Portuguese Government until 2020 [55,58]. For the period 2020-2030 and 2030-2050 average annual growth rates increases of $1.3 \%$ and $1.5 \%$ in power demand were considered. The cost of coal, natural gas and fuel oil are described in Table 5 [[59], page41] and were herein used as a reference to Portugal, despite originally these refer to Europe, in the case of natural gas imports prices, to IEA countries, in the case of crude oil imports prices and to countries from the OECD (Organisation for Economic Co-operation and Development), in the case of steam coal imports prices. Despite the volatility of average annual natural gas prices, we found that for industrial consumers the average of the last 3 years prices variation (from 2010 to 2013) between Portugal and Europe has been very proximate to zero and lower in Spain [60]. The model considers that natural gas prices in Spain are $15 \%$ lower than in Portugal, each year.

The costs of wind onshore, wind offshore, solar PV (photovoltaic), solar thermal and wave technologies were assumed to decrease with time due to the further development of the technologies and scale effects, as shown in Table 6 [4,59,61-63].

For the evolution of electricity demand in Spain the same methodology was considered [4]. For the period 2020-2030 and 2030-2050 average annual growth rates increases of $1.1 \%$ and $1.4 \%$ in power demand were considered.

Commodities prices are those used in Current Policies Scenario in the World Energy Outlook 2012 [[59], page41] assumed here to be also those in Portugal, as presented in Table 5. Natural gas costs are herein considered 15\% lower in Spain, each year, relative to the same costs in Portugal, given that Spanish generators scale is larger and therefore it is expectable that a better negotiation margin may exists for them. Analysis considering natural gas prices lower in Spain relative to Portugal by $5 \%$ each year was also considered. Crude oil and coal costs are equal in both countries as well as in the
Table 6

Evolution of investment costs.

\begin{tabular}{llllllllrr}
\hline Technology & Life & 2010 & 2015 & 2020 & 2025 & 2030 & 2035 & 2040 & 2050 \\
\hline Wind onshore & 25 & 1217 & 1200 & 1200 & 1175 & 1150 & 1000 & 990 & 900 \\
Wind offshore & 25 & 3300 & 3000 & 2840 & 2520 & 2200 & 2125 & 2050 & 1900 \\
Solar PV & 25 & 2550 & 2000 & 1540 & 1370 & 1200 & 1100 & 1000 & 800 \\
Solar central & 25 & - & 6993 & 6731 & 5874 & 5051 & 4373 & 3694 & 2200 \\
Solar through & 25 & 3574 & 3467 & 3360 & 3092 & 2904 & 2737 & 2569 & 2200 \\
Waves & 25 & 5650 & 5650 & 4070 & 3710 & 3350 & 3188 & 3025 & 2700
\end{tabular}

Values expressed in $€ 2010 / \mathrm{kW}[4,59,61-63]$.

rest of Europe. Technology costs and their evolution in Portugal and Spain are considered identical in both countries as with the rest of Europe (Table 6). Investments in nuclear in Spain were not considered as an option. The interconnection capacity PortugalSpain and Spain-Portugal is assumed to evolve with a three years delay compared to what is planned, with three GW of commercially available capacity by 2018. Other international interconnections were not considered.

\section{Results}

Comparing the optimized total system costs in both scenarios, it is found that in an open system the total system costs decrease by $1.5 \%$ relative to those in a closed system. If we consider natural gas prices 5\% lower in Spain relative to Portugal, instead of 15\%, total system costs decrease by $1.3 \%$ in an open system relative to a closed one. In an open system scenario, when natural gas prices are considered 5\% lower in Spain instead of 15\%, optimized system costs decrease by $0.9 \%$.

The analysed scenarios are presented below in both scenarios when natural gas prices are 15\% lower in Spain concerning the evolution on installed capacity, generation per technology and interconnection capacity and use. Generally, they reflect each of the systems endowments and the interplay dynamics between demand and supply. Despite neighbours, Portugal and Spain have different daily habits and $1 \mathrm{~h}$ difference time-zones which reflect on their electricity demand patterns. Finally, the different system costs categories are analysed.

Table 5

Evolution of commodities prices.

\begin{tabular}{|c|c|c|c|c|c|c|c|c|c|c|}
\hline Indicator & Units & 2011 & 2015 & 2020 & 2025 & 2030 & 2035 & 2040 & 2045 & 2050 \\
\hline Crude oil & $€ 2010 / \mathrm{bbl}$ & 107.6 & 118.4 & 128.3 & 135.7 & 141.1 & 145 & 154.9 & 165.5 & 176.8 \\
\hline Natural Gas & $€ 2010 / \mathrm{Mbtu}$ & 9.6 & 11.2 & 12.1 & 12.9 & 13.4 & 13.7 & 13.8 & 13.9 & 14 \\
\hline Coal & $€ 2010 /$ ton & 123.4 & 110 & 115 & 119.2 & 122.5 & 125 & 129.8 & 134.7 & 139.8 \\
\hline
\end{tabular}

Values expressed in real terms $€ 2010$, considering $1 €=\$ 1.287$ and $i_{2011}=3.7 \%$ [59] Current Policies Scenario. 


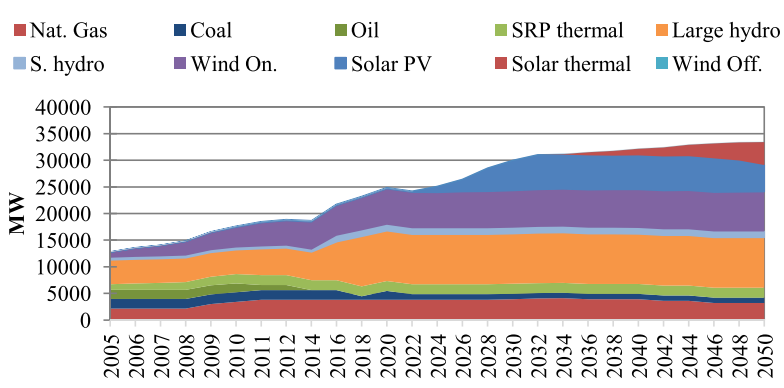

(a) close

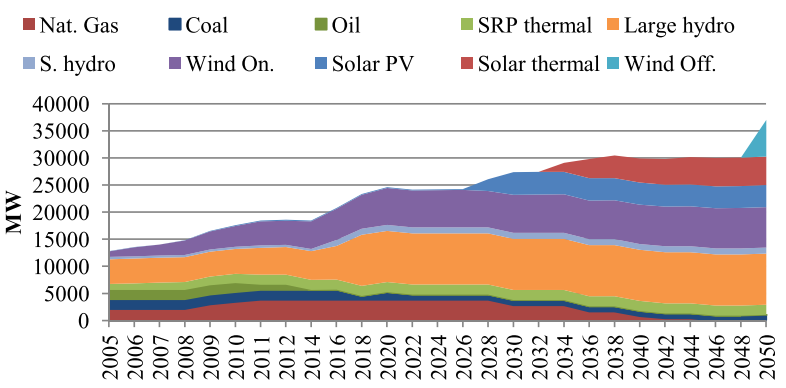

(b) open

Fig. 2. Portuguese installed capacity in a) closed and b) open system.

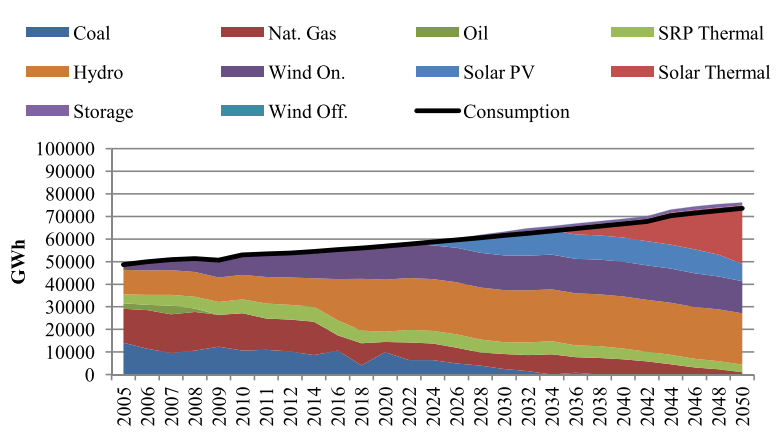

(a) close

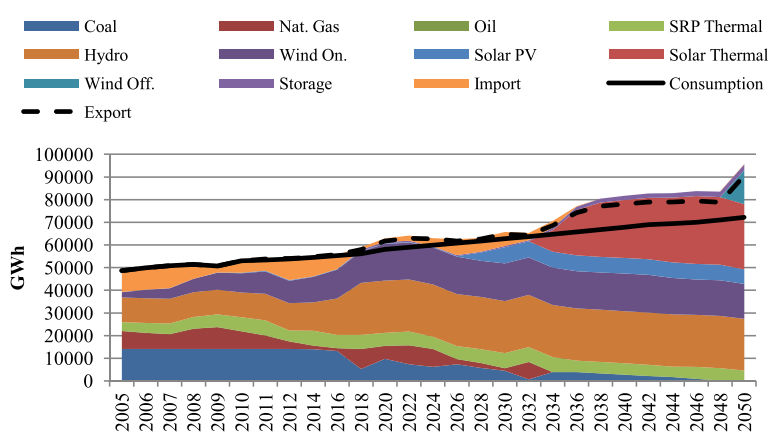

(b) open

Fig. 3. Portuguese electricity generation in a) closed and b) open system.

\subsection{Capacity}

The outcomes of the analysis show that in terms of capacity expansion both scenarios are indifferent in the period 2011-2016. In the subsequent period, until 2050, more investments are made installing capacity in Portugal each year under a closed system except in the year 2050. The greatest differences appear in installed capacity investments based in natural gas, from 2030 to 2050, which occur in a closed system and tend to disappear in an open system, as shown in Fig. 2. Additional coal installed capacity investments also occur in a closed system, from 2020 to 2050, relative to an open one, despite at a much smaller scale.

The availability of RES makes the electricity more competitive in Portugal in the longer run, mainly due to the harsh $\mathrm{CO}_{2}$ restrictions in place. Overall, solar installed capacity is higher in a closed system rather than in an open one. In particular, investments in solar PV begin earlier, in 2024, and are higher under a closed system compared to an open system, while investments in solar thermal are not as significant as in an open system, despite these begin

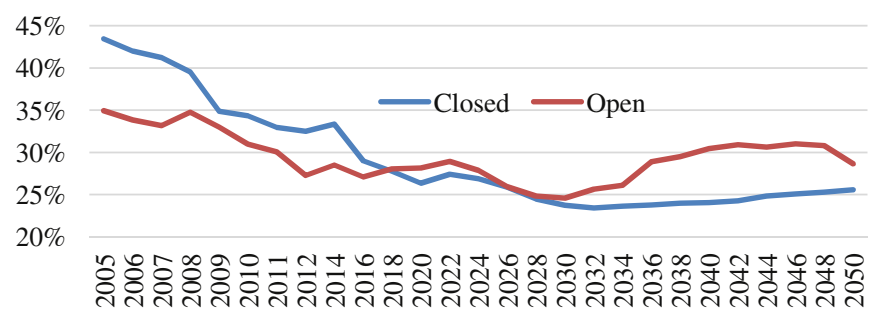

Fig. 4. Average annual capacity factor in closed versus open system (\%). around the same year, in 2032, in both scenarios. Finally, under an open system, the model decides to invest in wind offshore by 2050 . That may be explained by the possibility to export electricity generated using endogenous and renewable low carbon emissions resources, to support the decarbonisation in Spain.

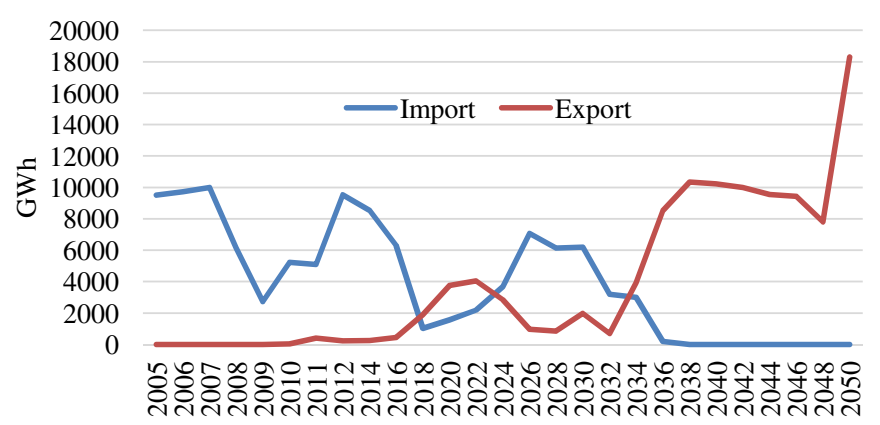

Fig. 5. Average annual imports and exports.

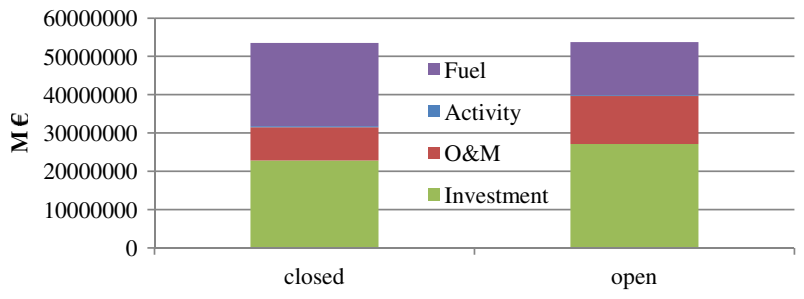

Fig. 6. Costs categories. 
Table 7

Level of use of existent interconnection capacity available for commercial activity.

\begin{tabular}{|c|c|c|c|c|c|c|c|c|c|c|c|}
\hline & 2010 & 2014 & 2018 & 2022 & 2026 & 2030 & 2034 & 2038 & 2042 & 2046 & 2050 \\
\hline SP-PT & $45 \%$ & $68 \%$ & $4 \%$ & $8 \%$ & $27 \%$ & $24 \%$ & $11 \%$ & $0 \%$ & $0 \%$ & $0 \%$ & $0 \%$ \\
\hline PT-SP & $17 \%$ & $1 \%$ & $7 \%$ & $15 \%$ & $4 \%$ & $7 \%$ & $15 \%$ & $39 \%$ & $38 \%$ & $36 \%$ & $54 \%$ \\
\hline
\end{tabular}

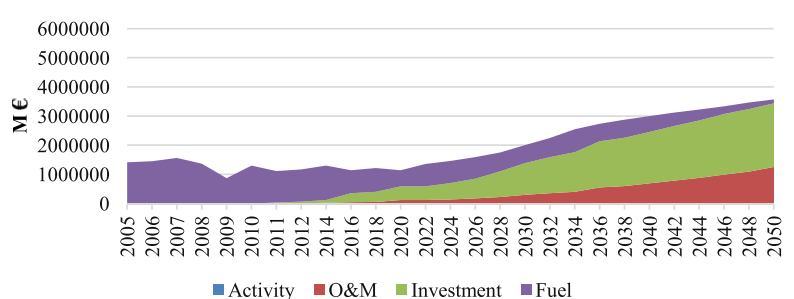

(a) close

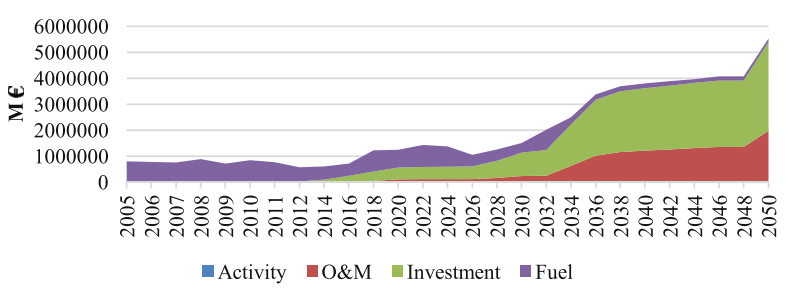

(b) open

Fig. 7. Portuguese electricity system costs in a) closed and b) open system.

\subsection{Production}

As shown in Fig. 3, in the longer-run, there is more electricity generation in the Portuguese open system, both due to the possibility of exporting electricity and from a higher use of the storage systems. In the period from 2018 to 2030, generation is still significantly supported by coal and natural gas generation, in both scenarios, while in an open system, imports are also significantly. Conventional generation is gradually eliminated in the remaining period as $\mathrm{CO}_{2}$ restrictions become more stringent. In an integrated system scenario, from 2032 on, Portugal becomes mainly an exporter of electricity, a balance also verified from 2018 to 2022, but interrupted by a positive imports balance of electricity between 2024 and 2030. While the first period transition to being electricity exporter is made through the increased production from hydro, wind onshore and natural gas, by 2040 the electricity exported is mainly produced from RES, such as hydro, solar and wind, including onshore and offshore.

In the whole period of analysis, coal is the most used conventional technology under an integrated system, while under a closed system, the most used conventional technology is natural gas. Wind generation is higher, each year, since 2018, under an open system as is the use of solar thermal technology, since 2034. On the other hand, solar PV is more used in a closed system rather than in an open one. Finally, storage is most used in an open system, increasingly from 2036 until the end of the period.

The increase in electricity production, particularly from RES, enables the system to use its installed capacity more effectively by achieving a higher average annual capacity factor, as shown in Fig. 4, particularly from 2030 until the end of the period. While the investment on RES naturally brings the average annual capacity factor down due to their low availability, the possibility to export electricity in periods with excess RES allows a better management of the installed capacity which results in a higher annual capacity factor and an increased cost-effectiveness of the investment.

\subsection{Interconnection}

In an integrated electricity system, Portugal becomes a net exporter by 2034, as shown in Fig. 5. While before 2018 and from 2024 to 2034 there is a positive imports balance for Portugal, in 2034 continuous Portugal becomes an electricity exported to Spain, leading to the investment in alternative RES technologies such as solar and wind, including offshore technologies in 2048.
The results of modelling an open electricity system in Portugal interconnected with Spain, show that only in 2050 new interconnection capacity in the direction Portugal-Spain will be required. In the meantime, the available interconnection capacity built until 2018 is far from being used at full capacity, as shown in Table 7, where the use of the existent capacity estimated by the model is shown in the period 2014-2050. The figure of the base year 2010 is historical and is included as a referential for comparison.

\subsection{Costs}

While considering an integrated Portuguese system, optimized total system costs decrease by $1.5 \%$ relative to when Portugal is considered a closed system. If natural gas prices difference in Portugal and Spain is assumed at 5\% level instead of $15 \%$, total system costs decrease by $1.3 \%$ in an open system relative to a closed one and $0.9 \%$ between open systems.

Fig. 6 shows the total system costs categories in both scenarios, which span from investment costs, operation and maintenance (O\&M) costs, activity costs and fuel import costs. It can be seen that in an open scenario, the most significant costs are investment and O\&M costs, while in a closed system scenario the most significant costs are fuel costs, whose volatility and future uncertainty are higher when compared to investment costs and, consequently, represent higher risk for stakeholders.

Fig. 7 illustrates the above cost categories along the analysed period. As it is perceptible, in the initial period the most significant costs are those associated with the activity of the system, while arriving to the end of the analysed period these tend to disappear and investment and O\&M costs assume scale. It is worth mentioning that in a closed system, fuel costs are significant almost up until the end of the period while in an open system from 2034 on these become minor until the end of the period.

\section{Conclusions}

The Spanish electricity system is roughly five times larger than the Portuguese and its cost competitiveness is testified by a history of export balances of its electricity. Nonetheless, when subject to stringent and strong environmental constraints, the high potential for RES in the small Portuguese system can lead to a shift in the import balances, with Portugal becoming a net exporter.

While most modelling works estimate the evolution of the Portuguese electricity system by considering a closed and isolated 
system, this can lead to the underinvestment in new generation capacity and increased risk. In fact, the modelling of the joint Portuguese and Spanish electricity systems points to an opportunity for Portugal to develop its use of non-conventional RES such as solar and wind, including offshore, and at the same time improves the cost-effectiveness of its electricity generation capacity through increased average annual capacity factors. For that reason, despite the current financial crisis, the retreat in the incentives for new renewable capacity in Portugal should be looked into cautiously. Also the most important costs categories in an open system are investment and O\&M costs relative to fuel costs in a closed system scenario. This means that lower costs risk are achieved in an integrated system as future fuel costs are more uncertain.

Responses to the challenges arising from the transition to a competitive low-carbon economy should not be dealt with in isolation by national Governments. Investing in cross-border and internal grid infrastructure can contribute to achieving both costeffective integration of RES electricity and internal electricity market goals. Transmission infrastructure benefits renewable integration because destination markets for variable renewable are enlarged. This can reduce storage requirements and backup capacity needs, thereby reducing the costs of integrating RES into the grid.

\section{Acknowledgements}

This work has been supported by the Portuguese Science and Technology Foundation (FCT) through the MIT-Portugal Program and the FCT scholarship SFRH/BD/42988/2008. The fourth author would also like to acknowledge FCT support under project grant PEst-C/EEI/UI0308/2011, the Energy for Sustainability Initiative of the University of Coimbra and the R\&D Project EMSURE Energy and Mobility for Sustainable Regions (CENTRO 070224 FEDER 002004).

\section{References}

[1] da Graça Carvalho M, Bonifacio M, Dechamps P. Building a low carbon society Energy 2011;36(4):1842-7. http://dx.doi.org/10.1016/j.energy.2010.09.030.

[2] Wiseman J, Edwards T, Luckins K. Post carbon pathways: a meta-analysis of 18 large-scale post carbon economy transition strategies. Environ Innov Soc Trans 2013;8:76-93.

[3] European Commission, Com(2011) 112 final. A roadmap for moving to a competitive low carbon economy in 2050 ec.europa.eu/clima/policies/ roadmap; 2011 [last accessed 30.07.13].

[4] European Climate Foundation. Roadmap 2050: a practical guide to a prosperous, low carbon EuropeIn Technical and economic assessment, vol. I; 2011. www.roadmap2050.eu; 2011 [last accessed 30.07.13].

[5] Ruska M, Kiviluoma J. Renewable electricity in Europe. Current state, drivers and scenarios 2020 www.vtt.fi/inf/pdf/tiedotteet/2011/T2584.pdf; 2011 [last accessed 30.07.2013].

[6] European Commission, Com(2011) 885/2 final. Energy roadmap 2050 ec. europa.eu/energy/energy2020/roadmap; 2011 [last accessed 30.07.13].

[7] European Wind Energy Association (EWEA), EU energy policy to 2050. Achieving 80-95\% emissions reductions www.ewea.org; 2011 [last accessed 30.07.13].

[8] Zervos A, Lins C, Muth J. Re-thinking 2050: a 100\% renewable energy vision for the european union www.rethinking2050.eu; 2010 [last accessed 30.07.13].

[9] Lund $\mathrm{H}$. Large-scale integration of wind power into different energy systems. Energy 2005;30(13):2402-12.

[10] Ostergaard PA. Comparing electricity, heat and biogas storages impacts on renewable energy integration. Energy 2012;37(1):255-62. http://dx.doi.org 10.1016/j.energy.2011.11.039.

[11] Ferreira HL, Garde R, Fulli G, Kling W, Lopes JP. Characterisation of electrical energy storage technologies, Energy 53.

[12] Lund H, Andersen AN, Ostergaard PA, Mathiesen BV, Connolly D. From electricity smart grids to smart energy systems. A market operation based approach and understanding. Energy 2012;42(1):96-102. http://dx.doi.org/ 10.1016/j.energy.2012.04.003.

[13] AlKhal F, Chedid R, Itani Z, Karam T. An assessment of the potential benefits from integrated electricity capacity planning in the northern Middle East region. Energy 2006;31(13):2316-24. http://dx.doi.org/10.1016/j.energy. 2006.02.003.
[14] Ostergaard PA. Geographic aggregation and wind power output variance in Denmark. Energy 2008;33(9):1453-60. http://dx.doi.org/10.1016/j.energy. 2008.04.016.

[15] Van Beeck N. Classification of energy models. Netherlands: Tilburg University \& Eindhoven University of Technology; 1999.

[16] Nakata T. Energy-economic models and the environment. Prog Energy Combust Sci 2004;30:417-75.

[17] Bhattacharyya SC, Timilsina GR. A review of energy system models. Int J Energy Sect Manag 2010;4(4):494-518.

[18] Connolly D, Lund H, Mathiesen B, Leahy M. A review of computer tools for analyzing the integration of renewable energy into various energy systems. Appl Energy 2010;87(4):1050-82.

[19] Pina A. Supply and demand dynamics in Energy systems modeling [Ph.D. thesis]. Instituto Superior Técnico da Universidade de Lisboa; 2012.

[20] Pandey R. Energy policy modelling: agenda for developing countries. Energy Policy 2002;30(2):97-106. http://dx.doi.org/10.1016/S0301-4215(01) 00062-3.

[21] Urban F, Benders R, Moll H. Modelling energy systems for developing countries. Energy Policy 2007;35(6):3473-82. http://dx.doi.org/10.1016/j.enpol. 2006.12.025.

[22] Kagiannas A, Didisz T, Askounis D, Psarras J. Strategic appraisal of energy models for Mozambique. Int J Energy Res 2003;27:173-86.

[23] Campodónico N, Binato S, Kelman R, Pereira M, Tinoco M, Montoya F, et al. Expansion planning of generation and interconnections under uncertainty www.psr-inc.com/psr/download/papers/; 2003 [last accessed 07.12.13].

[24] Rosen J, Tietze-Stckinger I, Rentz O. Model-based analysis of effects from large-scale wind power production. Energy 2007;32(4):575-83. http:// dx.doi.org/10.1016/j.energy.2006.06.022.

[25] Haller M, Ludig S, Bauer N. Bridging the scales: a conceptual model for coordinated expansion of renewable power generation, transmission and storage. Renew Sustain Energy Rev 2012;16(5):2687-95. http://dx.doi.org/ 10.1016/j.rser.2012.01.080.

[26] Ludig S, Haller M, Schmid E, Bauer N. Fluctuating renewables in a long-term climate change mitigation strategy. Energy 2011;36(11):6674-85. http:// dx.doi.org/10.1016/j.energy.2011.08.021.

[27] Pina A, Silva C, Ferrão P. Modeling hourly electricity dynamics for policy making in long-term scenarios. Energy Policy 2011;39(9):4692-702.

[28] Pina A, Silva C, Ferrão P. High-resolution modeling framework for planning electricity systems with high penetration of renewables. Appl Energy 2013;112:215-23.

[29] Deane J, Chiodi A, Gargiulo M, Gallachóir BPO. Soft-linking of a power systems model to an energy systems model. Energy 2012;42(1):303-12. http:// dx.doi.org/10.1016/j.energy.2012.03.052.

[30] Krajacic G, Duic N, da Graça Carvalho M. How to achieve a 100\% RES electricity supply for Portugal? Appl Energy 2011;88(2):508-17. http://dx.doi.org/ 10.1016/j.apenergy.2010.09.006.

[31] Haller M, Ludig S, Bauer N. Decarbonization scenarios for the EU and MENA power system: considering spatial distribution and short term dynamics of renewable generation. Energy Policy 2012;47:282-90. http://dx.doi.org/ 10.1016/j.enpol.2012.04.069.

[32] Foley AM, Gallachóir BPÓ, Hur J, Baldick R, McKeogh EJ. A strategic review of electricity systems models. Energy 2010;35(12):4522-30. http://dx.doi.org/ 10.1016/j.energy.2010.03.057.

[33] Botterud A, Mahalik M, Conzelmann G, Figueiredo Silva R, Vilela S, Pereira R. Multi-agent simulation of generation capacity expansion decisions. In: Electricity market, 2008. EEM 2008. 5th international conference on European; 2008. pp. 1-6. http://dx.doi.org/10.1109/EEM.2008.4579097.

[34] Malik AS, Kuba C. Power generation expansion planning including large scale wind integration: a case study of Oman. J Wind Energy; 2013:7. http:// dx.doi.org/10.1155/2013/735693.

[35] International Atomic Energy Agency. A computer code for power generating system expansion planning. User's manual, http://www-pub.iaea.org/MTCD/ Publications/PDF/CMS-16.pdf; 2001.

[36] Ahmad Rouhani GV, Nikkhah M. Generation expansion planning considering renewable energies. Am J Eng Res (AJER) 2013;2:276-86.

[37] Shinwari MF, Latif M, Ahmed N, Humayun H, Qureshi I, ul Haq I, et al. Optimization model using wasp-iv for pakistans power plants generation expansion plan. J Electr Electron Eng (IOSR-JEEE) 2012;3(2):39-49.

[38] Loulou R, Remme U, Kanudia A, Lehtila A, Goldstein G. Documentation for the TIMES model - part I www.etsap.org/Docs/TIMESDoc-Intro.pdf; 2005 [last accessed 30.07.13].

[39] Gouveia JP, Fortes P, Seixas J. Projections of energy services demand for residential buildings: insights from a bottom-up methodology. Energy 2012;47(1):430-42. http://dx.doi.org/10.1016/j.energy.2012.09.042.

[40] Oliveira C, Antunes CH. A multi-objective multi-sectoral economy-energyenvironment model: application to Portugal. Energy 2011;36(5):2856-66. http://dx.doi.org/10.1016/j.energy.2011.02.028.

[41] Seixas J, Fortes P, Dias L, Dinis R, Alves B, Gouveia J, et al. Low carbon roadmap: Portugal 2050-Energy and waste GHG emissions. Study for the Executive Committee of the Climate Change Commission., Tech. rep; January 2012.

[42] Gerbelová H, Versteeg P, Ioakimidis C, Ferrão P. The effect of retrofitting Portuguese fossil fuel power plants with CCS. Appl Energy 2013;101(C):280-7.

[43] Figueiredo N, da Silva PP. Integration of the south-west spot electricity markets: an update. In: International association for energy economics 12 th European energy conference; 2012. 
[44] International Energy Agency (OECD/IEA). Energy technology systems analysis Programme www.etsap.org; 2009.

[45] Loulou R, Labriet M. ETSAP-TIAM: the TIMES integrated assessment model Part I: model structure. Comput Manag Sci 2008;5(1-2):7-40.

[46] Rede Eléctrica Nacional (REN), Diagramas de carga horários, www. centrodeinformacao.ren.pt, [last accessed 30.07.13]

[47] Red Eléctrica de Espanha (REE), Produción eólica en tiempo real, www.ree.es/ operacion/curvas eolica.asp, [last accessed 30.07.13].

[48] Red Eléctrica de Espanha (REE). Información de mercado: E-SIOS www.esios. ree.es; 2013 [last accessed 30.07.13].

[49] Amorim F, Vasconcelos J, Abreu IC, da Silva PP, Martins V. How much room for a competitive electricity generation market in Portugal? Renew Sustain Energy Rev 2013;18:103-18.

[50] Rede Elétrica Nacional (REN), Dados Técnicos REN, www.centrodeinformacao. ren.pt, [last accessed 30.07.13]

[51] Rede Eléctrica Nacional (REN), Sistema de Informação de mercados de energia elétrica: SIMEE., www.mercado.ren.pt, [last accessed July 30.07.13].

[52] Directive 2009/28/EC (23.04.2009). Official J Eur Union; 2009. L 140/16 (05.6.09).

[53] Portuguese Government. NREAP national renewable Energy Action Plan Portugal ec.europa.eu/energy/renewables; 2010.

[54] Amorim F, Vasconcelos J, Abreu IC, da Silva PP, Martins V. Assessment of legacy generation contracts' costs in the future portuguese electricity system.
In: European energy market (EEM), 2012 9th international conference; 2012. pp. 1-4. http://dx.doi.org/10.1109/EEM.2012.6254647.

[55] Cabral PD. Plano National de Ação para as Energias Renováveis e as perspectivas de futuro para a Produção em Regime Especial Renovável. In Conferência da APREN 2012-A sustentabilidade do setor elétrico; 2012.

[56] Renewable Energy Policy Network for the 21st Century (REN21). Renewable global status report. Update, www.ren21.net; 2013 [last accessed 25.10.13].

[57] Red Eléctrica de Espa na, Informes del sistema elétrico español, www.ree.es, [last accessed 30.07.13].

[58] Ministry of Finance of the Portuguese Government. Orçamento do Estado para 2013 www.min-financas.pt; 2012 [last accessed November, 2012].

59] International Energy Agency (OECD/IEA). World energy outlook 2012; 2012.

[60] European Statistical Office (Eurostat). Gas prices for industrial consumers, from 2007 onwards - bi-annual data appsso.eurostat.ec.europa.eu/nui/ submitViewTableAction.do; 2013 [last accessed 11.12.13].

61] International Energy Agency (OECD/IEA). Energy technology perspectives; 2010.

[62] International Renewable Energy Agency (IRENA). Renewable energy technologies: cost analysis series concentrating solar power www.irena.org; 2012 [last accessed 30.07. 13].

[63] Wave Energy Centre, Wave Energy Centre, www.wavec.org, [last accessed 30.07.13], 2011. 